\title{
Allogeneic hematopoietic stem cell transplantation in mycosis fungoides"
}

\author{
Transplante alogênico de células-tronco hematopoiéticas em micose fungoide
}

Angelo Atalla ${ }^{1}$

Denise Bittencourt Siqueira ${ }^{3}$

\author{
Abrahão Elias Hallack Neto \\ Gabriela Cumani Toledo ${ }^{3}$
}

\begin{abstract}
Mycosis Fungoides is typically an indolent disease in early stages. However, approximately $30 \%$ of patients have advanced staged disease at presentation and $20 \%$ will develop it at some time. These patients have a poorer prognosis with a median survival of 2-4 years. The only curative option for mycosis fungoides may be hematopoietic allogeneic stem cell transplantation. We report the case of a patient with mycosis fungoides in an advanced stage (IIB), refractory to treatment options. She underwent allogeneic hematopoietic stem-cell transplantation (allo-HSCT). The patient remains in complete remission nineteen months after allo-HSCT. Allogeneic transplantation can alter the natural history of mycosis fungoides and should be considered in patients who have refractory disease or short-lived responses with standard therapies.
\end{abstract}

Keywords: Hematopoietic stem cell transplantation; Lymphoma, T-Cell, cutaneous; mycosis fungoides

Resumo: Micose Fungoide é tipicamente uma doença indolente em estágios iniciais. No entanto, aproximadamente $30 \%$ dos pacientes têm doença avançada na apresentação e $20 \%$ irão desenvolvê-la em algum momento. Esses pacientes têm um pior prognóstico com uma sobrevida média de dois a quatro anos. A única possibilidade de cura é o transplante alogênico de células-tronco hematopoiéticas. Relatamos o caso de uma paciente com micose fungoide em estágio avançado (IIB), refratária às opções terapêuticas e que foi submetida a um transplante alogênico de células-tronco hematopoiéticas. A paciente permanece em remissão completa 19 meses após o procedimento. O transplante alogênico é capaz de mudar a história natural da micose fungoide e deve ser considerado em pacientes com doença avançada e refratária aos tratamentos disponíveis.

Palavras-chave: Linfoma cutâneo de células T; Micose fungóide; Transplante de células-tronco hematopoéticas

\section{INTRODUCTION}

Mycosis fungoides (MF) is the most common subtype of primary cutaneous T-cell lymphomas, with an annual incidence of 0.36 cases per 100,000 personyears. ${ }^{1,2}$ MF affects men twice as often as women, is more common in black people, and manifests with higher incidence over the age of $50 .{ }^{3}$ The prognosis for MF depends on the age and clinical stage of the patient. ${ }^{4}$

It is characterized initially by scaly, non-infiltrative, erythematous or hypopigmented plaques, persistent, of varying sizes, and featuring intense itching.
In the advanced stages ( $>$ or $=$ IIB) it becomes deeply infiltrated, ulcerated, violet staining, with nodules and tumors appearing that can become infected. Belatedly it can spread to lymph nodes and visceral organs. ${ }^{1,5}$ Approximately $30 \%$ of patients have advanced staged disease with generalized erythroderma or tumor at the time of presentation, and $20 \%$ will develop advanced disease.,4 The correct diagnosis of MF can take years because of its similarity to other benign skin conditions. In the USA, it can take about six years from the time symptoms begin until the

Received on 13.12.2012.

Approved by the Advisory Board and accepted for publication on 06.01.2013.

* Work perfomed at the University Hospital - Federal University of Juiz de Fora (HU-UFJF) - Juiz de Fora (MG), Brazil.

Conflict of interest: None

Financial funding: None

MD, Master's degree in Internal Medicine, Federal University of Rio de Janeiro (UFRJ) - Head of Unit of Hematology and Bone Marrow Transplantation, University Hospital from Federal University of Juiz de Fora (HU-UFJF). Associate Professor, Department of Internal Medicine, UFJF - Juiz de Fora (MG), Brazil.

MD, PhD in Hematology, Universidade de São Paulo (USP) - Associate Professor, Medical School, Universidade Federal de Juiz de Fora (UFJF) - Juiz de Fora (MG), Brazil.

Medicine Student - Hospital Maternidade Therezinha de Jesus, Faculdade de Ciências Médicas e da Saúde de Juiz de Fora (SUPREMA)- Juiz de Fora (MG), Brazil.

C일 by Anais Brasileiros de Dermatologia 
diagnosis of MF, and some patients require multiple biopsies over the years. ${ }^{1}$

The chronic nature of the disease results in many patients being treated with multiple therapies, including: PUVA, radiotherapy, corticosteroids, alpha-interferon, chemotherapy, and immunotherapy.s Patients with advanced disease have a median survival of only two to four years; refractory patients are considered incurable with chemotherapy alone and most of these therapies are palliative. ${ }^{3,6,7}$

There is hope that Hematopoietic Stem Cell Transplants (HSCT) have the potential to provide prolonged remissions or a possible cure for advanced MF; however, their role is not well defined. ${ }^{6-8}$ We report the case of a female patient with MF, with approximately 13 years of evolution and subjected to several treatments but obtaining low response. The advanced stage and the lack of therapeutic options had led to an indication of allogeneic HSCT (allo-HSCT). The effect of HSCT in the patient's illness in a follow-up of 19 months is present here.

\section{CASE REPORT}

A 44-year-old white woman observed an erythema in the sternal region that progressed to involvement of the whole body in the form of urticarial plaques. The picture remained stable with topical and systemic steroids for eight years. Progression was observed with elevated and pruritic patches and plaques with purulent discharge from secondary infection on an extensive portion of the body surface.

When the patient came to our service, we performed a skin biopsy with immunohistochemistry that revealed cutaneous lymphoproliferative disease compatible with anaplastic large T-cell lymphoma focally CD30+ or Histiocytic sarcoma. Bone marrow biopsy was normal. CHOEP (cyclophosphamide, doxorubicin, etoposide, vincristine and prednisone) chemotherapy was initiated, totaling eight cycles, with minimal initial response in plaques and pruritus, but reappearing at the end of the eighth cycle. A new skin biopsy showed cutaneous T-cell lymphoma with epidermotropism, CD45+ and CD3+ (suggesting MF). Staged as IIB (T3-N0-M0), with $80 \%$ affected area, and presenting the most advanced lesions in the trunk, breasts and legs.

Subcutaneous interferon 3,000,000U was initiated, three times a week, gradually increasing to $12,000,000 \mathrm{U}$ and radiotherapy in tougher skin areas in the right groin. Major improvement of the lesions was obtained with interferon, but this had to be suspended because of non-hematological toxicity and disease progression. Gemcitabine, $1000 \mathrm{mg} / \mathrm{m}^{2}$ per week, was initiated. There was a significant regression of lesions, but recurrence was noticed at the end of the sixth cycle.
Her condition progressively worsened despite partial and temporary improvements with the various treatment modalities. The patient's skin was diffusely infiltrated (Figures 1 and 2) with patches, plaques, and tumors. The patient was referred to Euryclides de Jesus Zerbini Transplants Hospital, in São Paulo, and a reduced-intensity conditioning (RIC) allogeneic HLA matched sibling transplant was performed. After conditioning with fludarabine and melfalan she received peripheral blood stem-cells from her brother. Graft-versus-host-disease (GVHD) prophylaxis was done with mycophenolate mofetil and cyclosporine.

Engraftment took place on $\mathrm{D}+11$ and the patient was discharged from the hospital on D+14, with complete remission. Skin biopsy of residual hyperpigmented patches (Figure 3) showed GVHD without evidence of lymphocyte atypia. The patient has been in complete remission (Figures 4 and 5) for more than one year without treatment or any signs of GVHD, and peripheral blood mononuclear cells are $100 \%$ donor.

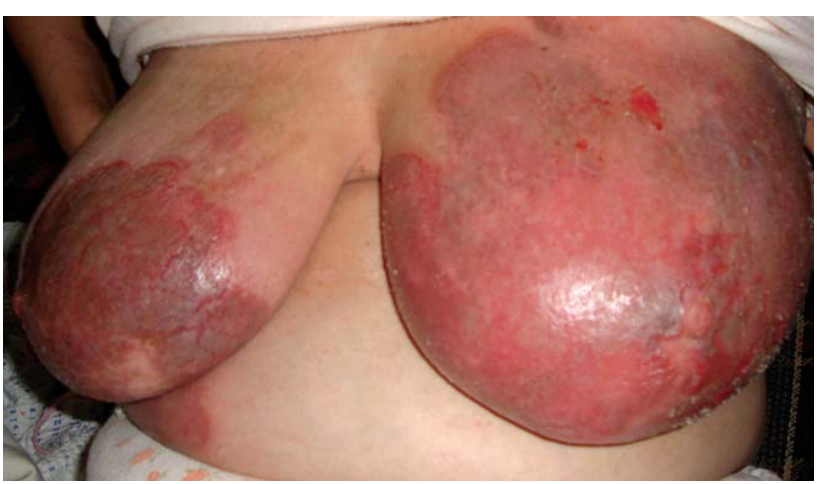

FIGURE 1: Mycosis fungoides lesions in breasts

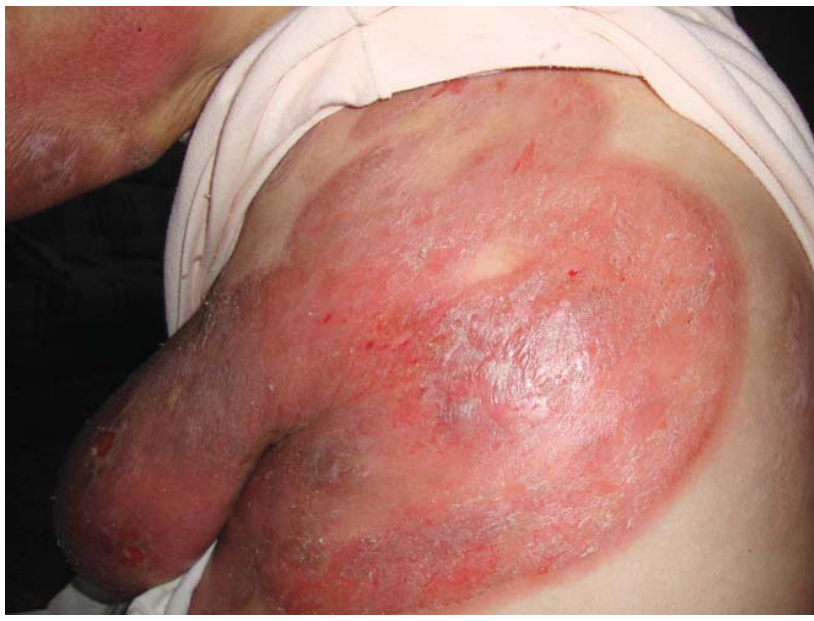

FIGURE 2: Mycosis fungoides lesion in breast extending to the back 


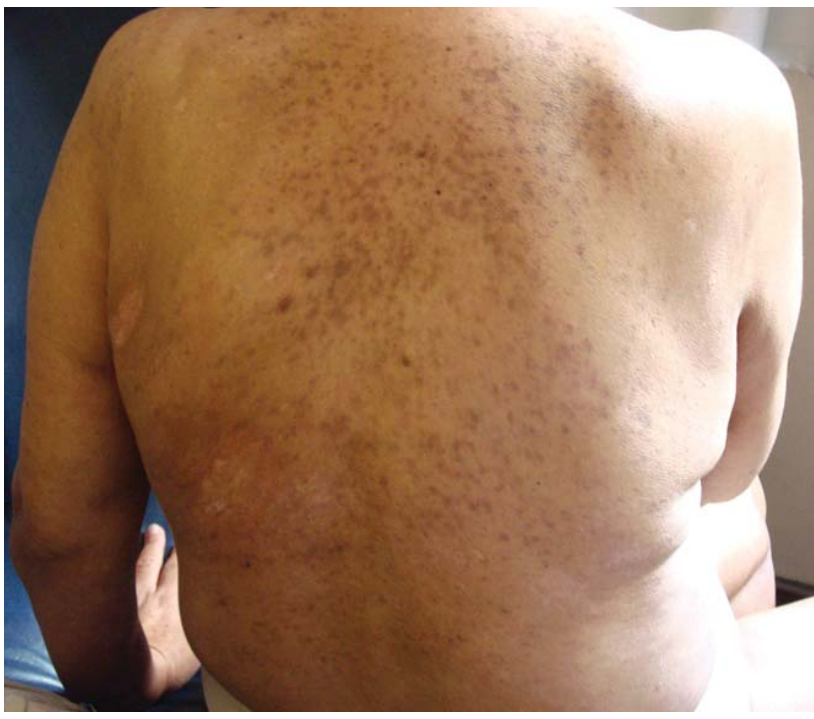

FIGURE 3: Graft-versus-host-disease - hyperchromic macules on the back

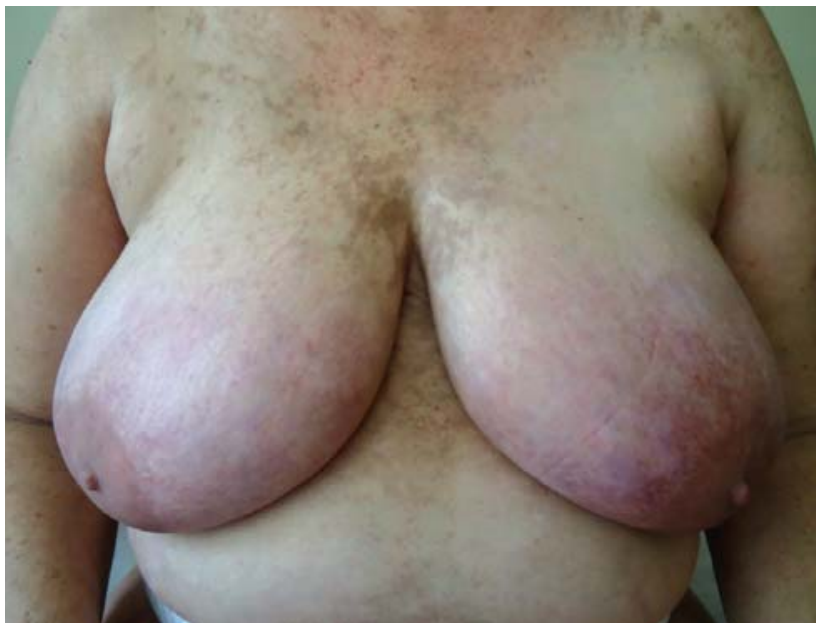

FigURE 4: Remission of mycosis fungoides lesions after allogeneic hematopoietic stem cell transplantation

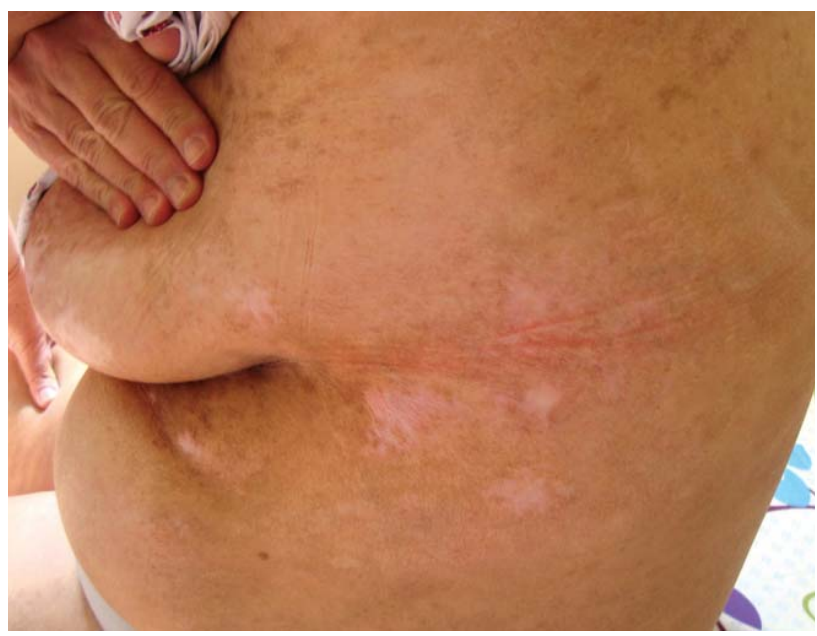

FIGURE 5: Remission of mycosis fungoides lesions after allogeneic hematopoietic stem cell transplantation

\section{DISCUSSION}

Advanced MF is associated with a poor outcome. Allo-HSCT has proved to be an effective therapy in $\mathrm{MF}$, demonstrating a decrease in the relapse rate and an overall increase in disease-free survival compared with conventional therapy. Allogeneic transplantation from a healthy donor not only eliminates the potential of graft contamination by tumor cells but also provides an immunologic antitumor effect, known as graft-versus-lymphoma (GVL). ${ }^{8,9}$ Although only a few patients have been treated with allo-HSCT until now, the results are consistent and promising. ${ }^{67,9,10}$

In the $W u$ et al. meta-analysis, $70 \%$ of patients undergoing allo-HSCT exhibited GVHD, the majority being mild to moderate, particularly in skin tissue. ${ }^{10}$ In the Molina et. al series of transplants, complete remission of skin lesions, tumors and ulcerated areas, itching and pain was observed in $100 \%$ of patients after allo-HSCT. ${ }^{8}$ The results of Duarte et al. showed that one year after allo-HSCT, $42 \%$ of their patients remained in remission. ${ }^{9}$ Our patient has achieved early remission and is maintaining it for over a year after transplantation. More than two thirds of patients with advanced stage CTCL, after receiving an alloHSCT, were alive and without evidence of disease for more than three years, which appears to be substantially higher than the median for disease-free survival, or even the overall rate for such patients. ${ }^{9}$

Most patients undergoing allo-HSCT previously received an average of seven different treatments before transplantation, similar to our patient who received five. However, despite these values, the optimal time for transplantation remains unknown; it is expected that, in the future, morbidity and the risk of recurrence may be even lower. Nevertheless, it is unquestionable that the allo-HSCT has a role of great importance in the management of CTCL, especially MF. The results observed in our patients are encouraging, and further studies are needed to answer the questions that still remain. 


\section{REFERENCES}

1. van Doorn R, Van Haselen CW, van Voorst Vader PC, Geerts ML, Heule F, de Rie M, et al. Mycosis fungoides: disease evolution and prognosis of 309 Dutch patients. Arch Dermatol. 2000;136:504-10.

2. Weinstock MA, Horn JW. Mycosis fungoides in the United States: increasing incidence and descriptive epidemiology. JAMA. 1988;260:42-6.

3. Whittaker SJ, Foss FM. Efficacy and tolerability of currently available therapies for the mycosis fungoides and Sezary syndrome variants of cutaneous T-cell lymphoma. Cancer Treat Rev. 2007;33:146-60.

4. Kim YH, Liu HL, Mraz-Gernhard S, Varghese A, Hoppe RT. Long-term outcome of 525 patients with mycosis fungoides and Sezary syndrome: clinical prognostic risk factors for disease progression. Arch Dermatol. 2003;139:857-66.

5. Yamashita T, Abbade LP, Marques ME, Marques SA. Mycosis fungoides and Sézary syndrome: clinical, histopathological and immunohistochemical review and update. An Bras Dermatol. 2012;87:817-30.

6. Schlaak M, Pickenhain J, Theurich S, Skoetz N, von Bergwelt-Baildon M, Kurschat P. Allogeneic stem cell transplantation versus conventional therapy for advanced primary cutaneous T-cell lymphoma. Cochrane Database Syst Rev. 2012;1:CD008908.

7. Jacobsen ED, Kim HT, Ho VT, Cutler CS, Koreth J, Fisher DC, et al. A large singlecenter experience with allogeneic stem-cell transplantation for peripheral T-cell nonHodgkin lymphoma and advanced mycosis fungoides/Sezary syndrome. Ann Oncol. 2011;22:1608-13.

8. Molina A, Zain J, Arber DA, Angelopolou M, O'Donnell M, Murata-Collins J, et al. Durable clinical, cytogenetic and molecular remissions after allogeneic hematopoietic cell transplantation for refractory Sezary syndrome and mycosis fungoides. J Clin Oncol. 2005;23:6163-71.

9. Duarte RF, Canals C, Onida F, Gabriel IH, Arranz R, Arcese W, et al. Allogeneic hematopoietic cell transplantation for patients with mycosis fungoides and Sézary syndrome: a retrospective analysis of the Lymphoma Working Party of the European Group for Blood and Marrow Transplantation. J Clin Oncol. 2010;28:4492-9.

10. Wu PA, Kim YH, Lavori PW, Hoppe RT, Stockerl-Goldstein KE. A meta-analysis of patients receiving allogeneic or autologous hematopoietic stem cell transplant in mycosis fungoides and Sézary syndrome. Biol Blood Marrow Transplant. 2009;15:982-90.

\author{
MAILING ADDRESS: \\ Angelo Atalla \\ Rua Catulo Breviglieri $s / n^{\circ}$ - Santa Catarina \\ 36036-110 - Juiz de Fora - MG \\ Brazil \\ E-mail: angeloatalla@yahoo.com
}

How to cite this article: Atalla A, Hallack Neto AE, Siqueira DB, Toledo GC. Allogeneic hematopoietic stem cell transplantation in mycosis fungoides. An Bras Dermatol. 2013;88(6 Suppl 1):S216-9. 